\title{
Documenting Communications and Communicating Documents: Developing Thesis Online Supervising in Distance Education
}

\author{
Djoko Rahardjo ${ }^{1}$
}

${ }^{1}$ Department of Library and Science Information, Universitas Terbuka e-mail: rahardjo@ecampus.ut.ac.id ${ }^{1}$

\begin{tabular}{|c|c|}
\hline Article Info & Abstract \\
\hline Article his & $m$ theses frequently $p$ \\
\hline & letely separate \\
\hline Jul & their mentors. This condition requires a great deal of time, energy, \\
\hline Revis & and money. Additionally, the institution made it difficult to control the process. This \\
\hline $30^{\text {th }}, 2021$ & study makes a recommendation for resolving this supervising dilemma. To accom- \\
\hline Accepted & plish these goals, an exploratory study is conducted through the design of a learning \\
\hline December 4 & management system that will be used to supervise processes. The design establishes a \\
\hline Published & synchronous and asynchronous communication system between students and men- \\
\hline December 5 & $\begin{array}{l}\text { tors. The outcome is a description of the thesis supervising process's requirements } \\
\text { and the thesis supervising model developed in Moodle. }\end{array}$ \\
\hline
\end{tabular}

Keywords: theses supervising; learning management system; distance education; mentoring

Kata Kunci: pembimbingan thesis; sistem manajemen pembelajaran; pendidikan jarak jauh; pendampingan

Pembimbingan tesis program magister seringkali menimbulkan kesulitan, terutama pada pendidikan jarak jauh, dimana sebagian besar mahasiswa tinggal di lokasi yang benar-benar terpisah dari pembimbingnya. Kondisi ini membutuhkan banyak waktu, tenaga, dan uang. Selain itu, institusi mempersulit proses kontrol. Studi ini membuat rekomendasi untuk menyelesaikan dilema pengawasan ini. Untuk mencapai tujuan tersebut, studi eksplorasi dilakukan melalui desain sistem manajemen pembelajaran yang akan digunakan untuk mengawasi proses. Perancangan membangun sistem komunikasi sinkron dan asinkron antara siswa dan mentor. Hasil yang diperoleh berupa deskripsi kebutuhan proses pembimbingan skripsi dan model pembimbingan skripsi yang dikembangkan di Moodle. 


\section{INTRODUCTION}

Universitas Terbuka (UT) is committed to open and distance education. The term "open" can be interpreted to mean that there are no restrictions on prospective students' age or graduation year. Distance learning refers to a method of education that does not involve face-to-face interaction but rather relies on media, both printed and non-printed, such as information and communication technology, broadcast television, and radio. Students at UT are expected to learn independently and on their own initiative. Students' success is determined by their ability to read and study instructional materials, to effectively utilize technology information and communication, to communicate effectively, to exercise self-discipline, to have a strong learning motivation, to manage their time efficiently, and to study regularly according to a specified learning schedule.

The UT Graduate Program offered a master's degree through a blended learning model. Each graduate program student is required to complete a final project, also known as a master's thesis, in the form of a scientific paper. The thesis is based on the findings of independent student research. The thesis may be empirical (field studies) or conceptual (literature studies) in nature and should be organized logically using scientific methods. One of the criteria for scientific writing is that it is free of plagiarism, in the sense that it clearly and responsibly cites the source of any information used. Survey research, experimental or quasi-experimental research, case studies, or other types of research are all possible. Program managers and supervisors facilitate students' research activities.

The UT Regional Office proposes supervisor recruitment from nearby government universities or other institutions. Supervisors must meet the academic requirements of the UT Graduate Program and are then determined by the UT Graduate Program Director's Decree. Each student is supervised by two supervisors, referred to as the First and Second Supervisors. Students may contact their assigned supervisor at any time during the guiding process, but particularly after the Guidance Decree is issued. Students are required to create a guiding plan in order to complete their thesis on time and with the quality required by scientific standards (method, time and place).

Thesis supervising is an interaction between students and supervisors during the thesis preparation process, with the goal of producing a thesis that adheres to academic standards and academic ethics. Throughout the guiding process, the Supervisor will provide input and correction on scientific substance relevant to the research topic, the accuracy of research methods, and scientific writing according to the supervisors' standards. Thus, the graduate program provides an option for anyone who wishes to continue their education without being constrained by time or location constraints.

Students continue to face obstacles during the thesis guiding process. As a service-oriented institution, the UT Graduate Program must be able to meet the needs of its students and provide satisfaction to its customers. This condition necessitates a commitment on the part of higher education leaders to satisfy their customers, one of which is continuous quality improvement, one of the efforts made to improve the thesis supervising process's quality.

While a blended model of thesis supervision is used to assist students, who are in the final stages of writing their thesis, the increased number of students and limited resources necessitated the development of a new model.

\section{Supervision of Thesis}

For students pursuing degrees, Todd, Smith, and Bannister (2006) argue that the thesis is work that requires students to conduct their own research and study on their own time. As a result, they need assistance to build the self-confidence necessary to succeed in their independent work. Students have a lot of freedom when it comes to selecting a thesis topic at UT. As a result, they will be able to work independently and improve their skills in time management, report writing, and interpersonal communication. The supervisor, on the other hand, may discover that they are directing about a topic they are unfamiliar with.

Students can become self-directed learners because they are able to organize their own work, according to Scholefield and Cox (2016). In many cases, this is the first-time students are given the opportunity to choose how they are evaluated, and they find it both empowering and demoralizing. The institution's moral, reputational, and financial wellbeing are directly linked to the success of its students, which is why supervision is so important. Thus, faculty members supervise their students in the context of university policy makers.

In contrast, Vilkinas (2007) found that most 
supervisors were task-oriented. They were able to help their students both emotionally and structurally in terms of academics. In some cases, academics collaborated with their students to conduct research projects. It was an honor to work with and observe the students as they grew academically and personally. Using this method, it was demonstrated that most study participants were task-focused and unable to fulfill paradoxical roles, as well as reflect on and learn from their supervisory abilities.

According to the research done by Can, Richter, Valchanova, and Dewey (2016), thesis supervisors and students are not adequately prepared for their roles. There was a lack of communication and genuine cooperation between them, which was the main source of their conflict.

Individual academic achievement and the reputation of the institution were directly linked to successful postgraduate supervision (Lemmer, 2016). Thesis supervision is distinct from other kinds of supervision. Aiming to promote lifelong learning through research is the primary goal, rather than academic advancement (Roets, 2016). It is important for mentors to help students who are not under their direct supervision generate their own knowledge. During the supervision period, it is essential to adapt to change. When students are establishing their research interests, learning new methodologies and acquiring new information, they will benefit greatly from the guidance of a mentor (Todd et al., 2006). Media could easily document the change in this online surveillance environment. While investigated supervisors and found that the majority of them were task-oriented. In terms of academics, they were able to help their students emotionally.

\section{Communicating Documents and Documenting Communication}

Students can pursue graduate studies at colleges that offer distance education thanks to the internet. With a growing student population and a wide range of student and mentor characteristics, graduate supervision in an unsynchronized online environment presents interesting challenges (Devos et al., 2016). Students relied on the support of their supervisors throughout the process, which necessitates further investigation.

Where as online monitoring focuses primarily on written communication and electronic drafts, offline monitoring includes physical and social proofs as well as spoken communication and drafts of content (Augustsson \& Jaldemark, 2013). It is also important to note that the quality of articulations enables us to distinguish between the various ways in which we use observations, perspectives, directions, and questions. It is critical that supervisors have an understanding of the natural world and the ability to communicate in a variety of ways when they need to give students more autonomy while supervising them online. Since they learn from both less-experienced experienced journalists, like the boss, as well as more learned peers like other students, students' involvement in the practice should help them develop their scholarly research as well as their writing skills.

To meet this expectation, supervisors and students participate in verbal or written communicative interactions. Learning is associated with these communicative interactions between students and supervisors in such a habit. The rise of computer-mediated communication may be a shining example of how improved methods of disseminating interactions between learners and mentors have emerged (Agustsson, 2017). In research papers, supervision entails communicating about argumentative, conceptual, real, individual, procedural, explanatory, and stylistic issues. To summarize, online supervision encompasses concerns about the information-exchange channel. In online supervision, it is necessary to choose an appropriate communication technology (Sussex, 2008).

\section{METHOD}

The researcher conducted an experiment with an LMS called Moodle in order to design an application for Thesis Online Supervising (TOS). It began with data collection through comparisons of existing designs. Moodle includes a variety of features that support the need for process supervision, such as information dissemination, group and personal communication, document uploading, and reviewing. With a description of how TOS works, applications can be easily traced in the event of technical difficulties, and the guidance process's results can be easily located. In conjunction with Black box testing is used in computer programming and program design to ensure that the output of a program is as predicted, given certain assumptions. The term "black box" is used because the executed program is not inspected (See Fig. 1). 


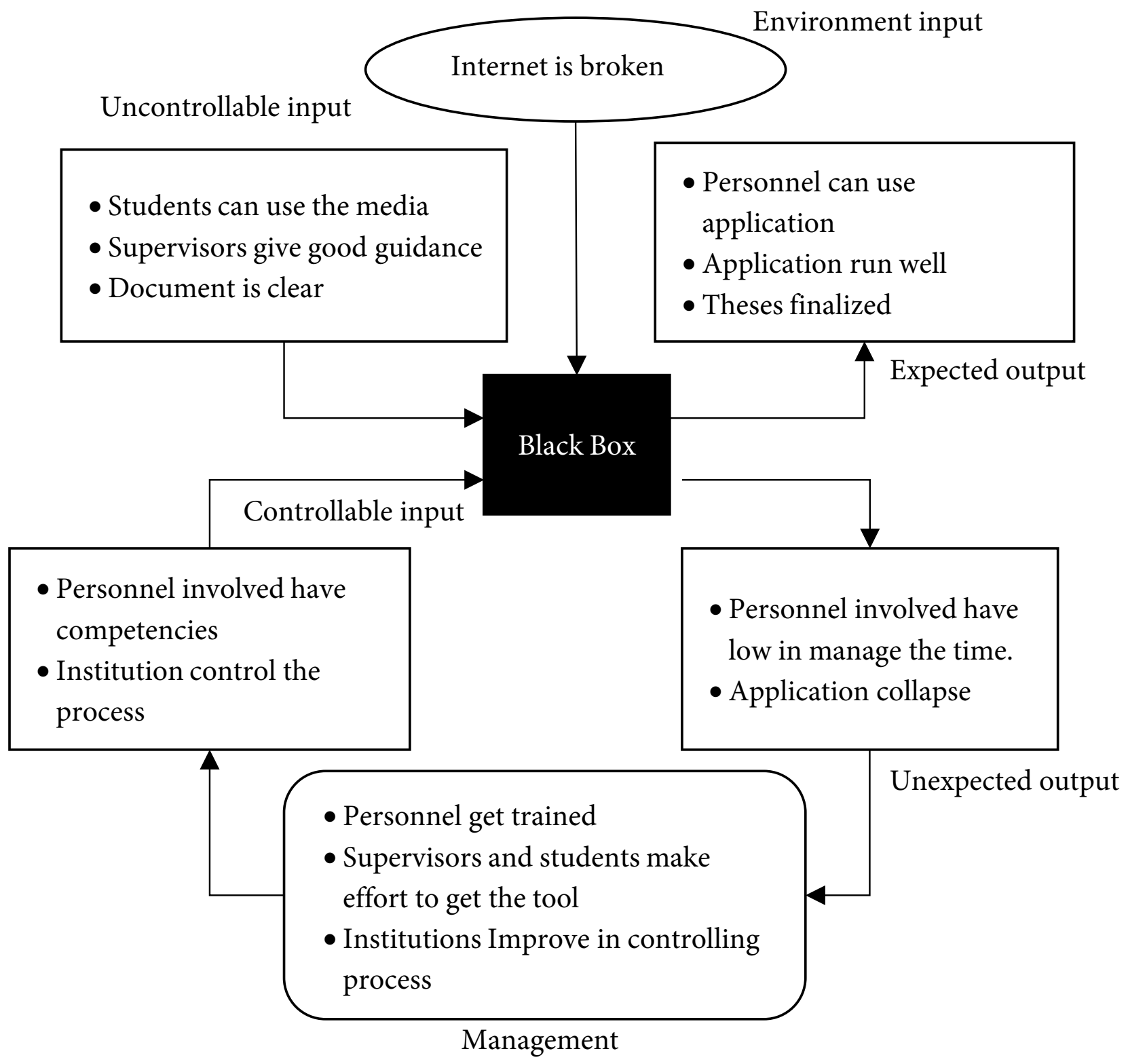

Figure 1. System Design

\section{RESULTS AND DISCUSSION}

According to the UT system, master's students are free to select their thesis topic. In TOS, a program's output is as expected. Online supervision involves considerations regarding the data-transfer channel. There is a requirement for selecting an appropriate communication innovation in virtual supervision (Sussex, 2008). While Scholefield D. (2016) stated that one of the benefits of a thesis endeavour is that it enables students to develop into independent learners because they are generally in charge of their own work. Typically, first-year students are given autonomy over the assessment process, which they frequently find both empowering and weakening (See Figure 2).

\section{UT's Thesis Online Supervising System}

TOS as a system that facilitates the online thesis guidance process is carried out through the Moodle application by maximizing features consisting of group mode, evaluation and filtering mode, reviewing mode, material presentation mode, discussion mode. The mode of grouping is the supervisory team and the supervised students are enrolled in the same course or class on Moodle. This will foster an atmosphere of collaboration between them. They will share information pertinent to their field of study with the members of their group. In Moodle, there is a feature evaluating and filtering mode. The feature prevents users from proceeding to the next step by assigning 


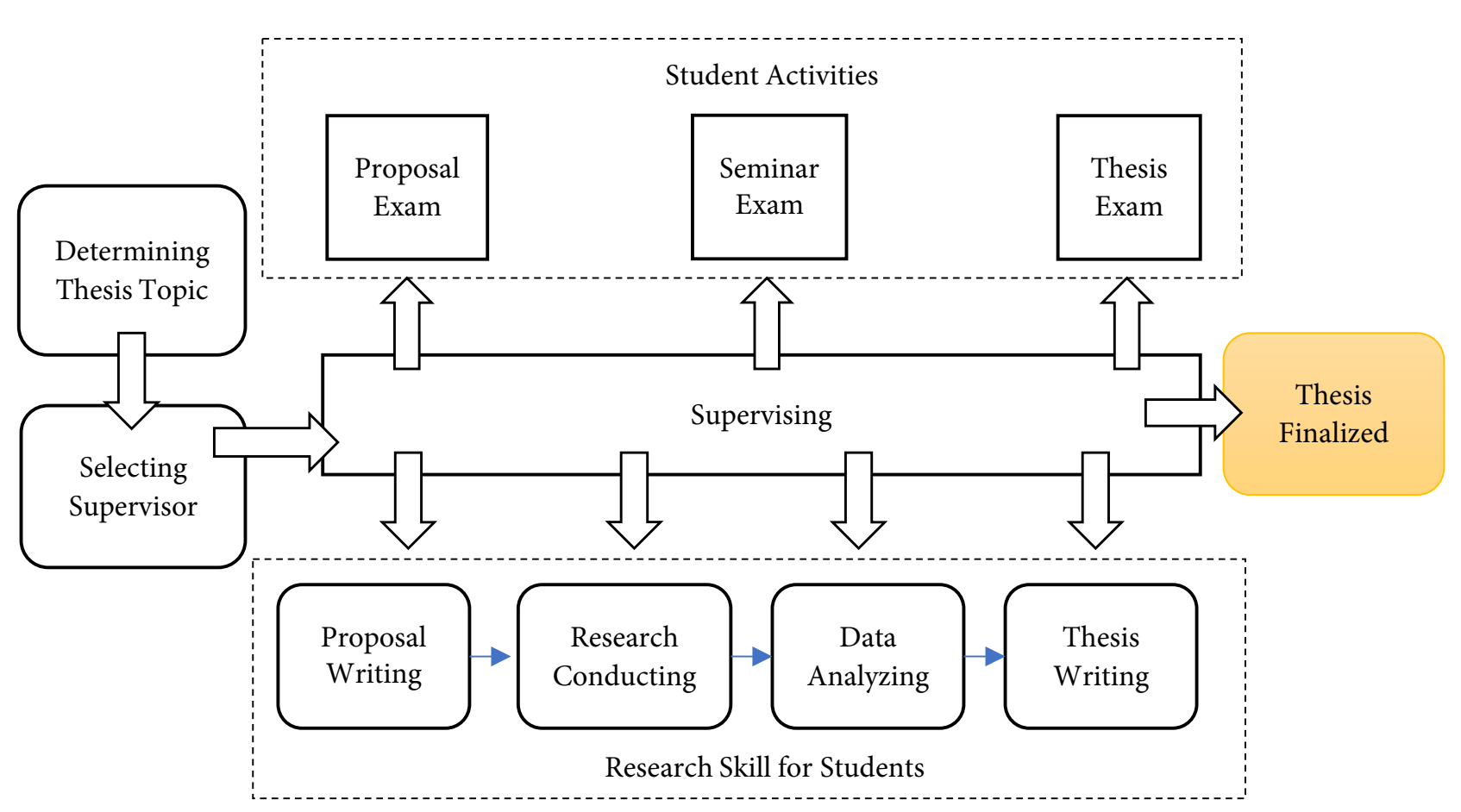

Figure 2. Thesis Supervising Process

them a low score. This section is used to assess the students' work. Students who submit eligible works will pass a particular section of the class.

The next feature is reviewing mode, the supervisor's primary responsibility is to review students' work. Moodle supports a variety of file types through this feature. In this instance, the researcher is reviewing a pdf file. Uploading tasks or assignments by students. Furthermore, a student supervising a master's program can use material presentation mode. This feature enables users to present content that may include text, images, and/or audio-visual elements. This will ensure that the students have a firm grasp of the subject under discussion. The supervising master program can be communicated with a student through discussion mode. This feature enables users to participate in a discussion forum. Every user is welcome to participate in the discussion to exchange experiences, resolve issues, and seek reference assistance.

\section{CONCLUSIONS}

According to (Devos et al., 2016), TOS serves as a hub for students seeking assistance with their master's final assignments. Students who require assistance must access this application in order to receive assistance.
The disadvantage of free thesis topic selection is that supervisors may find it inconvenient (Todd et al., 2006). The issue can be mitigated by assigning an appropriate supervisor to the students proposed topic. Faculty members must provide a diverse range of experts in order to successfully guide students to the final.

As a system, this OTS application serves as a resource center for students seeking assistance in completing their master's thesis. Numerous factors have been considered when designing this application, including the primary keywords 'communications and documentations'. Convergence communications between supervisors and students become critical for bridging the gap between information and knowledge requirements, especially when reviewing and commenting on a document. While documentation has the connotation of being manageable and archived. Educational institutions can use this application to keep track of all recorded documents and manage the system.

\section{ACKNOWLEDGEMENTS}

This research was financially supported by Universitas Terbuka Indonesia. Thank to the Late of Dr. Liestyodono B. Irianto, M.Si, my research collaborative colleague who provided the idea and help to insight and expertise that greatly assisted the research. 


\section{REFERENCES}

Augustsson, G., \& Jaldemark, J. (2013). Online supervision: a theory of supervisors' strategic communicative influence on student dissertations. Higher Education, 67(1), 19-33. doi:10.1007/s10734-013-9638-4

Can, E., Richter, F., Valchanova, R., \& Dewey, M. (2016). Supervisors' perspective on medical thesis projects and dropout rates: survey among thesis supervisors at a large German university hospital. BMJ Open, 6(10). doi:10.1136/bmjopen-2016-012726

Devos, C., Boudrenghien, G., Van der Linden, N., Azzi, A., Frenay, M., Galand, B., \& Klein, O. (2016). Doctoral students' experiences leading to completion or attrition: a matter of sense, progress and distress. European Journal of Psychology of Education, 32(1), 61-77. doi:10.1007/s10212-016-0290-0

Lemmer, E. M. (2016). The Postgraduate Supervisor Under Scrutiny: An Autoethnographic Inquiry. Qualitative
Sociology Review $-\underline{w w w . q u a l i t a t i v e s o c i o l o g y r e v i e w}$. org, 12(1).

Roets, L. (2016). Supervisory Practices in the Open and Distance Learning (ODL) Context: A Review. Gender \& Behaviour 14(1), 11.

Scholefield, D., \& Cox, G. (2016). Evaluation of a model of dissertation supervision for 3rd year B.Sc. undergraduate nursing students. Nurse Education in Practice, 17, 78-85. doi:10.1016/j.nepr.2015.11.006

Todd, M. J., Smith, K., \& Bannister, P. (2006). Supervising a social science undergraduate dissertation: staff experiences and perceptions. Teaching in Higher Education, 11(2), 161-173. doi:10.1080/13562510500527693

Vilkinas, T. (2007). An Exploratory Study of the Supervision of Ph.D./Research Students' Theses. Innovative Higher Education, 32(5), 297-311. doi:10.1007/ s10755-007-9057-5 